\title{
Viewpoints on the Development of Private Higher Dance Education
}

\author{
Chen $\mathrm{Li}$ \\ College of Music and Dance \\ Jiangxi University of Technology \\ Nanchang, Jiangxi Province 330098 China
}

\begin{abstract}
Along with the scientific development and social progress, the function of artistic education is becoming increasingly important, and music and dance major have received unprecedented development during the process of the implementation of quality-oriented education, thus proposing new requirement for the cultivation of talents. As a new force in Chinese higher education, private university has played an inestimable part. It is a significant task to hold characteristic specialty for higher education in the popularization age, and a critical carrier to highlight the school-running characteristics of universities. During the process of implementing dance education, private university needs to understand its own advantages and disadvantages, face the prominent problems correctly, analyze the reasons and find out solutions. It should comprehend the subjective and objective elements for the slow development, re-inspect the talent cultivation orientation, prominent features as well as advantages, and gradually enhance its competitiveness.
\end{abstract}

Key words: private; higher education; dance; development

\section{INTRODUCTION}

Private education started relatively late in China, and was unpopular for a very long time. Currently, under the general situation that quality-oriented education is vigorously advocated and market economy is developing rapidly, the development of dance education in private university has received broader stage. As a constituent of private higher education, dance education in private university is equipped with the characteristic of artistic education besides the identity of private higher education. No matter it is elite education or mass education, the enlightenment of artistic education to people's heart and soul is undisputable. With the development of the society and the progress of the society, music and dance education have received unprecedented development. At present, the tendency has becoming increasingly stronger that dance major is being hold in various private universities in China. If we investigate dance education in private university more carefully, we may find a joint point between the specialty and popularization for dance major, as well as between academic study and employment for dance major students, which can also be of significant guidance to the research of dance education in private university and its benign development.

\section{Advantages of private higher education}

Throughout the several decades of the development of private higher education in China, we can find that it possesses certain advantages: firstly, it has specific property right incentive and clear responsibilities, which can guarantee the import of advanced and efficient management, and is also to the benefit of dividing the relationship of responsibility, right and profit. The second advantage is its flexible mechanism and management. The basic form of the management system in private university is headmaster-in-change system under the leadership of board of directors. The administration organization composed of board of directors and headmaster form efficient procedures of studying and deciding school management matters. Under such management system, major school-running matters are decided by the board of directors, while the headmaster is responsible for carrying out the decisions of the board of directors, which is beneficial to exerting the group decision-making role of the board of directors so as to guarantee the validity of the decisions, and is also favorable for the headmaster to be fully devoted to the inner management of the school and improving work efficiency and benefit. The third advantage is its school-running 
characteristics. Private university possesses the autonomy of school-running, so it can organize teaching and carry out management according to demands of the market, changes of the society, characteristics of the students and its own realities, and it is easier to form its own school-running characteristics. It can set its own majors according to the market, and its reaction to market demands will be faster than other universities. Private university pays a lot of attention to the demands of society to talents so as to adjust major setup in time. Some universities put forward the concept of "order education", which means the university will cultivate talents according to the demand of the society.

The current educational situation of traditional major takes state-run education as the main body, and private university as the supplement. With the decisions of the new government, in the next few years, we are bound to embrace the bright future of school-running by nongovernmental sectors. The increasing of Chinese higher education relies on nongovernmental sectors for the most part. Private university should take advantage of the opportunities and the decisions of the country, exert the existing advantages and characteristics, integrate the resources, so as to find the market positioning of the development of private university and conduct diversified competition with state-run universities.

\section{Prominent problems that need to be addressed} by dance education in private university

Dance education is a unique cultural style. Correspondingly, dance education should also be a behavior that spread and inherit culture. It means that we should reflect on the school-running orientation of dance education, and explore its cultural significance and special intellectual viewpoint comprehensively from social and public perspective, so as to make up an integrate dance education.

1) Private university is a new force in Chinese higher education, and to hold dance higher education is the representation of a university's comprehensiveness and diversification; also, the cultivation of talents is also the key to the quality of Chinese dance higher education. At present, various kinds of dance art schools can be seen everywhere which have very similar teaching model and management methods. If dance education in private university cannot make breakthroughs in the creation of distinctive school-running models and form its own features in talent-cultivation, it may be a far-reaching dream to improve its cultural character and professional status.

2) Currently, Chinese dance higher education is developing rapidly and is facing a transformation period; also, higher dance education is developing quickly and is waiting for improvement, so it is an urgent task to bring in teaching staff with high quality. At present, the standard of the teaching staff in dance education of private university is uneven. Though some private universities have high standard for bringing in teachers, the real outstanding talent would still choose state-run universities first. Therefore, some practical measures need to be taken to address this problem if private university wants to bring in teachers with high quality.

3) Dance education is detached from other humanistic and social science. On the basis of cultivating college students' artistic skills, dance education should pay more attention to the cultivation of students' art-appreciation ability, art-evaluation ability and the special art-insight. Also, dance education should transform dance and other humanistic and social science into comprehensive perception, i.e., the emphasis of dance quality-oriented education should be transferred from dance itself to the combination of other subjects such as the combination of aesthetics, philosophy, psychology, sociology and ergonomics. Professor Liu Qingyi once said, "The interdisciplinary theory of dance mainly includes theories of dance and inter-disciplines that are related to humanities and social sciences (dance aesthetics, psychology, anthropology, sociology and education) and researches of inter-disciplines related to natural sciences."

\section{The influencing factors of education development}

1) The influence of economic elements on the scale of private university is mainly reflected in students from various areas and the personal income of their families as well as the difference of the investment of social capital on private education. Such economic elements have impact on 
the quality of the students majoring in dance in private universities virtually. Students with good economic conditions have been learning dancing since very young, so their basis is relatively solid; on the contrary, many students just learn dancing for a year a two before the college entrance examination; therefore, the scores of their courses are not satisfactory.

2) Insufficient government support. During the development of private education, though the government has admitted the status and effect of private education in time, and has issued some policies and regulations favorable to the development of private education, the intensity, generally speaking, is not strong enough. There are unfair or inclined situations concerning many problems, which limited the development of private universities to a large extent.

3) The status, treatment and other problems of the teachers in private university are of critical importance to the development of private university. If the university wants to develop, it must be equipped with a teaching staff with excellence and stability. However, teachers in private universities do not have official authorized strength, thus are mobile and unstable. Though many private universities have made great effort in improving teachers' benefit, etting teachers involved in the university's management, enhancing teachers' treatment and stimulating teachers' initiative, they cannot guarantee teachers' stability either.

4) Improper understanding of private higher education, and lack of understanding, acknowledgement and support to private university. For a very long period of time, there have been negative remarks such as "Unnecessary Theory", "Profit Theory", "Skepticism Theory", "Poor-quality Theory" and so on, which have put private education in a dilemma.

5) Misunderstanding from the public. Since the general public does not understand, they have misunderstanding. The less understanding, the more misunderstanding. For a long time, the general public has been holing some misunderstanding in comprehension and cognition of private universities, and they lack understanding to the status, effect and development of private education.
6) Unfavorable influence of art enrollment policy and professional examination to private education. Private university does not have autonomous right to hold examinations, which result in the fact that the quality and quantity of students cannot be guaranteed.

\section{Feasible opinion on the development of dance education in private university}

On the basis of comparing the dance majors in state-run and private universities, this thesis aims to find the advantages of dance education in private university, the existing problems and try to solve them. It should know the subjective and objective elements for its slow development, re-inspect the development plan and talent cultivation positioning of dance majors. Also, it should change the traditional dance education ideology, update the teaching methods of dance major, open relevant newly-developing courses and cutting-edge majors, make its characteristics and advantages stand out and enhance its competitiveness gradually for better and quicker development.

1) Clear positioning. School-running and talent-cultivation purpose should be clear. In terms of "clear purpose", we mean that firstly, the school-runners should clearly realize such questions as "What kind of talents do we cultivate?" and "How to cultivate talents?" The fundamental purpose of dance education in private university is not to transfer acting and educating talents for professional dance troupes or schools whose number are very limited, but to satisfy the demands of large numbers of dance-lovers; in the meantime, to cultivate multi-skill dance talents with high comprehensive qualities for the entire dance career, even the whole society or all industries. The development of disciplines should have long-term plans, and combine long-term benefit with current benefit, and long-term goal with the short-term one. The school-running positioning should be further cleared, and talent-cultivation should be further diversified. The potential of school-running resources should be explored fully so that the students can enjoy a fulfilling school life here and also a bring future. Only in this way can be achieve favorable economic benefits. 
2) Teacher stability. Private university should spare no effort to cultivate a teaching staff with optimal structure, clear orientation and skillful teaching. It should also guarantee teaching quality and cultivate practical and innovative talents with high quality. Teaching staff is the key to the survival and development of private university. It should exert its advantage in having more autonomous right than state-run university in management system, operation mechanism and teaching. Also, it should set up advanced employment mechanism, reward the diligent and punish the lazy, select the superior and eliminate the inferior, and it also should make great effort in attracting and cultivating young and middle-aged teachers so as to guarantee the sustainable development of the university; it should strengthen the business relation with teachers in other schools, learn from other's strong points to offset one's weakness.

3) Opening up to run the school and explore development space actively. Firstly, it should unite with troupes and cultivate dance students together so as to attract more social sources for school-running. It should use the soft power and other advantageous platforms of troupes to develop itself. Besides, it can undertake various kinds of influential contests and activities so as to enlarge its school-running influence. Thirdly, it should develop off-campus practice base actively, and go on the way of industry-university-research so as to form the systematicness of "class-stage-class-stage".

4) Creating features. Under the general situation that compulsory education is basically popularized and higher education has generally realized popularization, it has become the only route for private university to create features and improve teaching and education quality. Correct school-running theory, scientific development plan are the premise of the survival and development of the school, while modern management system and operation mechanism are the basis of the development.

Firstly, it should start from teaching and learning, set up new, diversified and multi-dimensional education concept that adapt to the demands of the society. Secondly, it should update education concept, reform teaching methods, and select characteristic teaching content carefully. Thirdly, it should reform the teaching mode, curriculum system, teaching content, teaching methods and ways. Fourthly, it should pay high attention to practice, and strengthen the cultivation of students' artistic practice and ability. Fifthly, it should reinforce practice, artistic practice, graduation party and other practical teaching, and encourage students to participate in professional contests. Sixthly, it should embrace talent-cultivation purpose closely, integrate and optimize curriculums scientifically and reasonably, delete old and outdated teaching content, select teaching content with scientificity, advancement, practicability and innovation. Seventhly, it should formulate characteristic evaluation standard. Reasonable assessment and evaluation system is favorable to motivate students' initiative in linking theory with practice, and is beneficial to cultivating practical dance talents with higher humanistic quality.

\section{CONCLUSIONS}

Dance education in private university is still in the primary development stage. Under the steady situation that the government is striving to develop social forces for school-running, we should refer to the advanced school-running ideology and concepts in dance education development both at home and abroad, accelerate the development pace of private dance education, exert our own features and advantages, adopt our good points and avoid our shortcomings so as to make great contribution to the dance education in China.

\section{References:}

[1] Yu Ping. Comprehensive Discussion on Higher

Education Dance. Cultural and Art Press,2004;

[2] You Jiaying. Investigation and Research on Higher Dance Education. [Master Dissertation]. Beijing, Chinese Art Research Institue, 2007,04;

[3] Zheng Jinzhou. Education Culturology[M]. Beijing: People's Education Press, 2000.

[4] Jia Shaohua. Core Competitiveness and Promotion of Private University. Journal of Southwest University of Nationalities, 2004(10) 